\title{
Understanding Students in the Selection of Taxation Concentration Department: Quality Lecturers, Understanding Accounting, Understanding Taxation, and Student Interest
}

\author{
Aditya Pratama ${ }^{1, *}$, Siti Fatimah Zahra ${ }^{2}$, Sulistiyani ${ }^{3}$ \\ ${ }^{1}$ Prodi Study in Economics, Faculty of Economics, Jakarta State University, Indonesia \\ ${ }^{2}$ Prodi S1 Accounting, Faculty of Economics, Jakarta State University, Indonesia \\ ${ }^{3}$ Prodi Management, Faculty of Economics, University of Pamulang, Indonesia
}

Received July 12, 2020; Revised August 26, 2020; Accepted September 17, 2020

\section{Cite This Paper in the following Citation Styles}

(a): [1] Aditya Pratama, Siti Fatimah Zahra, Sulistiyani, "Understanding Students in the Selection of Taxation Concentration Department: Quality Lecturers, Understanding Accounting, Understanding Taxation, And Student Interest," Universal Journal of Educational Research, Vol. 8, No. 11, pp. 5610 - 5621, 2020. DOI: 10.13189/ujer.2020.081165.

(b): Aditya Pratama, Siti Fatimah Zahra, Sulistiyani (2020). Understanding Students in the Selection of Taxation Concentration Department: Quality Lecturers, Understanding Accounting, Understanding Taxation, And Student Interest. Universal Journal of Educational Research, 8(11), 5610 - 5621. DOI: 10.13189/ujer.2020.081165.

Copyright $\mathrm{C} 2020$ by authors, all rights reserved. Authors agree that this article remains permanently open access under the terms of the Creative Commons Attribution License 4.0 International License

\begin{abstract}
Professionals in the field of taxation have an important contribution to manage tax in a country. A country's biggest income comes from taxes. Indonesia is one of the countries with the largest economic growth in the world. Therefore, the potential for taxes received will certainly be large. For the amount of taxes received to be managed well, it requires many experts in the field of taxation. To meet the number of experts in the field of taxation, of course it can be obtained from universities that have accounting courses in the concentration of taxation. Higher education institutions in Indonesia annually graduate as many as 35,000 undergraduate accounting students. But not all students choose the field. Model test and MRA test for the variable Quality lecturers, Understanding accounting, Understanding taxation and student interest in taking accounting study programs, concentration in the field of taxation are the goals to be achieved. In this study also wanted to find out the magnitude of the effect on the variable relationship of Quality lecturers, accounting understanding, Understanding taxation and student interest in taking accounting study programs in the field of taxation concentration. This research was conducted with a simple
\end{abstract}

random sampling probability sampling method with a sample of 100 respondents from accounting students with taxation concentration. The data used are primary data through questionnaires. In this study, the model test and MRA test are used. The results of data analysis using model test and mra test show that the Quality lecturers have an effect on accounting understanding and Understanding taxation. The Quality lecturers, accounting understanding and Understanding taxation have a significant effect on the interest in choosing majors. Variable Understanding accounting and Understanding taxation as variables can strengthen the influence of Quality lecturers on the interests of majors selection.

Keywords Quality Lecturer, Understanding Accounting, Understanding Taxation, Student Interest

\section{Introduction}

Finance Minister of the Republic of Indonesia Sri Mulyani Indrawati quoted from DDTC News mentions that 
"a country incorporated in ASEAN is one of the world's markets that has a growing economy rapidly. In 2030, ASEAN was expected to become a group of countries with the fourth-largest economy in the world. Therefore, the accounting profession is required to have the same standard in controlling the economic area"[1]. With the application of the same standard of manpower qualifications in the field of accounting, the professional opportunity of accountants will be wider. This means that if the qualification standard is applied then an accountant can practice in 10 ASEAN countries.

Rector of UMY Gunawan Budiyanto based on his statement quoted from DDTC News mentions "graduate S1 accounting from college in Indonesia about 35 thousand per year, but the accountant already has a CPA certificate from IAPI until now new 2,064 people. For CPA accountants can already work in ASEAN countries because the international standards we have adopted"[2]. S1 is an undergraduate level of education known in Indonesia or known as Starta 1. based on the source above, the comparison of S1 accounting graduates with certified accountants is not comparable.

The large number of uncertified accounting graduates, of course, has an impact on accounting graduates to become accountants. With the cooperation between 10 ASEAN countries, it is hoped that certified accounting graduates in Indonesia can compete with other countries. With this information, of course, it can drive the increase in the number of certified accountants. This figure shows that Indonesia has the potential to become the country with the strongest accounting profession in the region..

Accounting presents information on circumstances that occur during certain periods of management or other interested parties to assess the performance conditions of the company[3], [4]. While in taxation use the term bookkeeping or recording, instead of using the term accounting. accounting science in the field of taxation is a part of accounting that arises from an element of specialization that demands expertise in a particular field. Accounting in the field of taxation is created because of a basic principle that is regulated in the taxation LAW and its formation is affected by the taxation function in implementing it as a government policy. The purpose of accounting in the field of taxation is to establish a substantial tax owed based on the financial statements compiled by the company.

Selection of future job careers based on considerations of work eligibility to be obtained in the future[5]. With the increasing number of accountant graduates, each individual must have good quality in order to be able to compete in the world of work[6] . Especially with the current MEA, the wider competition faced because it not only competes with Indonesian people but with other countries as well. Therefore, every individual needs to prepare himself to have a good advantage or quality to be ready to compete in the workforce. It is not only must-have knowledge, but interpersonal skills are of paramount importance to make the individual succeed in achieving the desired career[7], [8].

In understanding a certain subject of learning interests is important as well to consider. A student who has a great interest in certain courses will focus more on more than other students. Then, because of the intensive concentration of the material that allows the student to learn more enterprising and finally achieve the desired achievement.

Great learning interests tend to support the success of learning that results in achievement[9], [10]. The learning interest of students closely related to the use of good time to learn accompanied by satisfaction of the lecturer can improve the achievement[11], [12]. High Learning interests will be realized when students are aware of their responsibilities as students, to increase motivation and self-discipline to reach the desired target in understanding material. This learning interest was based on the interest to choose a career[12].

The study interest election relates to a career that you would like to achieve at the time of entering the workforce[13]. The level of student understanding of the material is expressed by how well a student has learned about what has been learned in this context. The mark of a student understands the material is not only demonstrated by the values in each subject but also if the student understands and can master the concepts associated with it. Quality of understanding has contributed to the selection of interest specification[14].

Interest is a tendency that causes one to strive to seek or attempt activities in a particular field. With interest, one will try to work in the field according to the majors or interests that he has chosen[15], [16]. Thus, students who have the interest to take the economics of accounting in the concentration of taxation certainly understand the taxation so that the graduates will be in the field of taxation such as employees of the Directorate General of Taxes, tax consultants, and the tax specialists in the company. The profession in the taxation field is needed so that the taxation mechanism in Indonesia can run well.

Based on the description above, this researcher wants to understand why students choose accounting majors that have a concentration in the field of taxation. In this case, what will be used as a measure to understand the desires of students in choosing accounting majors with a concentration in taxation are as follows:

1. to examine the effect of lecturer quality on accounting understanding.

2. to examine the effect of lecturer quality on tax understanding.

3. to examine the effect of lecturer quality on student interest in selecting majors.

4. to examine the effect of accounting understanding on student interest in selecting majors.

5. to examine the effect of understanding taxation on student interest in selecting majors 
6. to test the effect of understanding accounting as a moderating variable between the quality variables of lecturers and student interest in selecting majors

7. to examine the effect of understanding taxation as a moderating variable between the quality variables of lecturers and student interest in selecting majors

\section{Foundation Theory}

The main related theory that explains the attachment of each variable will be the subject of discussion. Some of the underlying theories used will be described as follows.

\subsection{Theory of Planned Behaviour}

The theory of planned behavior is a model of attitude used to predict a person's intent or interest to conduct a behavior[16]. When the decision is driven by an evaluation of the rationally and the consequences of behavior, both positive and negative consequences can affect a person's behavior. Theory Planned Behaviour explaining that one's intent or interest in committing a behavior or action becomes a key factor affecting a person's behavior[17].

Theory of Planned Behaviour to determine which factors affect students' interest, helping how we can change and forecast one's behavior. [18]. This theory is a major factor in determining individual interest, in conducting a specific behavior[19]. Interest is determined by 3 factors: the level in which an individual feels good or less (attitudes), a social influence affecting the individual to perform or not conduct behavior (subjective norms), and an easy or difficult person in conducting a behavior (perceived behavior control)[20].

\subsection{Student Interest Selection of Majors}

Interest is the urge of a desire that arises within a person after the occurrence of viewing, observing, or comparing that brings up a certain choice. These interests are from the external and internal thrust that reinforces each other[21]. Interest is important in knowing a person's talents. The study election interest can provide an overview of the basic capabilities that students already have in the determination of the interest.

\subsection{Quality Lecturers}

Qualified lecturers will be able to carry out their obligations. The obligation of a lecturer is at Tri Darma College which is contained in law No 12 the year 2012 about the college that content is, education, research, devotion[22]. The obligation of course must be balanced with technological advances. If a lecturer can improve the quality of obligations listed in Tri Darma College, it can describe the quality of a lecturer.

\subsection{Understanding Accounting}

The definition of accounting is a person's ability to know and understand about accounting. Understanding is not just knowing, but also demands that the subject of learning is able to make use of the material that has been understood. Accounting is a broad and complex set of knowledge, and the science of accounting can be seen from two sides of meaning, namely as a professional science (expertise) that is practiced in the real world as well as as one of the disciplines taught in universities. Understanding of accounting is also able to improve audit quality, taxation, and financial management capabilities[23]. Employers expect accounting graduates to have basic understanding, strong analytical skills in the business field[24]. In Understanding Accounting, interest in learning is also important to note. A student who has a great interest in accounting subjects will focus his attention more than other students [25].

\subsection{Understanding Taxation}

Knowledge and understanding of tax regulations is the process by which taxpayers know about taxation and apply that knowledge to pay taxes[26]. The level of understanding of taxation is important in determining tax attitudes and behavior of taxpayers in carrying out their obligations. Fulfillment of tax obligations will be carried out well if it is supported by a good understanding of taxpayers regarding tax regulations. This understanding makes it easier for taxpayers to carry out tax obligations.

\subsection{Conceptual Framework}

In this model of research will illustrate the relationship between Quality lecturers, understanding, and students' interest in determining the selection of majors. These variables will of course relate to each other. The three variables will be described in the following conceptual framework: 


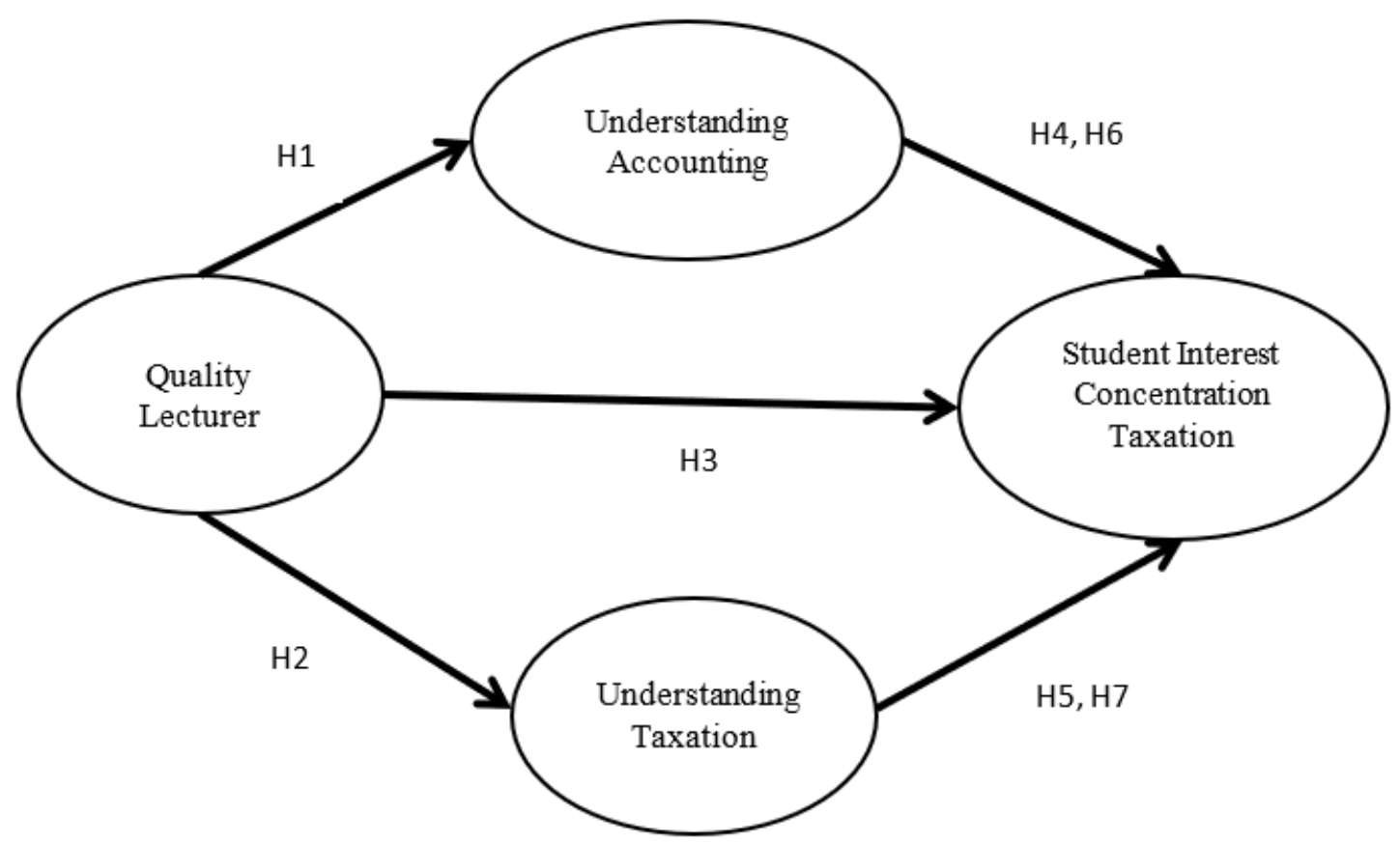

Figure 1. Conceptual Framework

\subsection{Hypothesis}

Based on the conceptual framework described above, the hypothesis is obtained as follows:

1) The quality of lecturers has an effect on accounting understanding.

2) The quality of lecturers has an effect on understanding taxation.

3) The quality of lecturers has an effect on students' interest in choosing majors.

4) Accounting understanding has an effect on student interest in choosing a major.

5) Tax understanding affects students' interest in choosing majors

6) Accounting understanding strengthens the effect of lecturer quality on students' interest in choosing majors.

7) Understanding of taxation strengthens the influence of lecturer quality on student interest in choosing majors.

\section{Research Methods}

The approach in this research is a quantitative approach or it can be defined as an investigation or investigation that is managed, systematic, data-based, critical, objective, and scientific of a particular problem, which is carried out with the aim of finding related answers or solutions. This research is a type of quantitative research with a survey research form. Quantitative research aims to show the relationship between variables, and this study also uses moderating variables, which can strengthen or weaken the relationship between the dependent variable and the independent variable.

\subsection{Populasi}

The population in this study were undergraduate accounting students who were registered as students in the 5th, 6th, 7th and 8th semesters of taxation concentration at Pamulang University with the total amount described in the table below.

Table 1. Research Population

\begin{tabular}{|c|c|}
\hline Semester & Number of Students \\
\hline V & 794 \\
\hline VI & 558 \\
\hline VII & 245 \\
\hline VIII & 755 \\
\hline Total & 2352 \\
\hline
\end{tabular}

Source: Office of the UNPAM Accounting Study Program

\subsection{Sampel}

The sample is a part of the population taken in a certain way which also has certain, clear, and complete characteristics which are considered to be representative of the population to be studied. Sampling using simple random sampling type Probability. The sample of this study were students of the undergraduate accounting department with a concentration in taxation at Pamulang University. The determination of the number of samples in this study is based on the Slovin formula.

The total population in this study amounted to 2532 . After using the Slovin formula with an error margin of $10 \%$, 
the result is 95.9. Based on this figure, the number of samples in this study was rounded off to a total sample of 100 people.

\subsection{Metode Analisis}

Before we discuss the method of analysis in this study. The data were obtained using a questionnaire with a Likert scale measurement variable. To analyze the answers to the questionnaire from respondents given using the provisions of the Likert scale, namely weighted values: 5 (strongly agree), 4 (agree), 3 (doubtful), 2 (disagree), 1 (strongly agree), disagree). The research data collection uses a questionnaire based on the theories which can be seen in the table 2.

To determine the feasibility of a data, all data will go through several stages of testing before testing the hypothesis. The initial stage of the feasibility test of a data using validity and reliability tests, if all data has passed the validity and reliability tests, it will be continued to the next testing phase. Furthermore, each variable will be retested with the classical assumption test in which there is a normality test, autocorrelation test, multicollinearity test, heteroscedasticity test. To determine whether there is an influence between the Quality lecturers, Understanding accounting, Understanding taxation and student interest in choosing a taxation concentration accounting study program. Statistical data will be analyzed linear regression. After the data passes a series of data feasibility tests, then a hypothesis test is carried out using the T test and the MRA test to find out what percentage of the effect of each variable is and whether the moderating variable is able to strengthen or weaken the influence of each of the tested variables.

Table 2. Research Indicators

\begin{tabular}{|c|c|c|c|}
\hline $\begin{array}{c}\text { Variables and Variable } \\
\text { Sources }\end{array}$ & Indicator & Statement Item & Scale \\
\hline Understanding accounting & $\begin{array}{l}\text { 1. Understanding accounting courses } \\
\text { 2. Understanding accounting makes it easier to get a job } \\
\text { 3. Interested because you want to get a job according to your } \\
\text { educational background }\end{array}$ & $\begin{array}{l}1,2,3 \\
4 \\
5\end{array}$ & Likert \\
\hline Understanding taxation & $\begin{array}{l}\text { 1. Knowledge of general tax provisions and procedures } \\
\text { 2. } \quad \text { Knowledge of tax functions } \\
\text { 3. }\end{array}$ & $\begin{array}{c}1,2 \\
3 \\
4,5\end{array}$ & Likert \\
\hline $\begin{array}{c}\text { Student Interest } \\
\text { Concentration of Taxation }\end{array}$ & $\begin{array}{l}\text { 1. Interested because it provides a lot of experience and } \\
\text { knowledge about taxes } \\
\text { 2. Will have a career in taxation after the completion of studies } \\
\text { 3. To solve existing taxation problems }\end{array}$ & $\begin{array}{c}1,2 \\
3,4 \\
5\end{array}$ & Likert \\
\hline Qualified Lecturer & $\begin{array}{l}\text { 1. } \quad \text { Teaching \& Academic Engineering } \\
\text { 2. } \quad \text { Personal } \\
\text { 3. }\end{array}$ & $\begin{array}{c}1 \\
2 \\
3,4\end{array}$ & Likert \\
\hline
\end{tabular}

Source: Data processed by researchers 


\section{Research Results}

\subsection{Respondents Overview}

Table 3. Respondent Characteristics

\begin{tabular}{|c|c|c|c|}
\hline Category & Information & Total & Percentage \\
\hline \multirow[t]{2}{*}{ Gender } & Male & 42 & $42 \%$ \\
\hline & Women & 58 & $58 \%$ \\
\hline \multicolumn{2}{|l|}{ Total } & 100 & $100 \%$ \\
\hline \multirow[t]{4}{*}{ Semester } & 5 & 18 & $18 \%$ \\
\hline & 6 & 27 & $27 \%$ \\
\hline & 7 & 24 & $24 \%$ \\
\hline & 8 & 31 & $31 \%$ \\
\hline \multicolumn{2}{|l|}{ Total } & 100 & $100 \%$ \\
\hline \multirow[t]{3}{*}{ Department/Concentration } & Tax & 100 & $100 \%$ \\
\hline & Audit & 0 & $0 \%$ \\
\hline & Sharia & 0 & $0 \%$ \\
\hline \multicolumn{2}{|l|}{ Total } & 100 & $100 \%$ \\
\hline
\end{tabular}

Source: Data processed

The number of questionnaires distributed by the number of students at Pamulang University is 100 respondents. Respondent characteristics are a description of the respondents studied. Respondent characteristics can be seen on the first sheet of the questionnaire in the respondent data section which includes gender, Regular, and Semester. Respondent data can be seen more clearly in the table 3 .

\subsection{Validity Test Results}

Validity test to determine whether a questionnaire is valid or not. Below is the result of the validity test of each variable present in the study. The basis for decision making in the validity test is significant $<5 \%$, so the questionnaire item is declared valid. If the significant value $>5 \%$ value then the item is declared invalid or with a validity test decision if rcount $>$ rtable value at significant $5 \%$ then the questionnaire item is declared valid. If tcount $<$ rtable value, the item is declared invalid.

In this study, the validity test used a $99 \%$ belief rate whereby $D F=n-2$. The value $\mathrm{N}$ in this study was $22-2$ so that the value of $\mathrm{df}=20$. Thus, obtaining the $\mathrm{r}$-table value $=$ 0.420 , the second basis is said to be valid if the significance value is below 0.05 . Based on the table 4 , it can be declared valid because all the statement items contained in the variable have a calculated value greater than the r-table and also the significance value is below 0.05 .

Table 4. Validity test Results

\begin{tabular}{|c|c|c|c|c|c|}
\hline Variable & Statement item & R-Count & $\mathrm{r}$ table & Sig. (2-Tailed) & Description \\
\hline \multirow{4}{*}{ Quality lecturers } & KD1 & 0,815 & 0,420 & .000 & Valid \\
\hline & KD2 & 0,762 & 0,420 & .000 & Valid \\
\hline & KD3 & 0,729 & 0,420 & .000 & Valid \\
\hline & KD4 & 0,699 & 0,420 & .000 & Valid \\
\hline \multirow{5}{*}{$\begin{array}{l}\text { Understanding } \\
\text { accounting }\end{array}$} & PA1 & 0,599 & 0,420 & .000 & Valid \\
\hline & PA2 & 0,765 & 0,420 & .000 & Valid \\
\hline & PA3 & 0,684 & 0,420 & .000 & Valid \\
\hline & PA4 & 0,786 & 0,420 & .000 & Valid \\
\hline & PA5 & 0,698 & 0,420 & .000 & Valid \\
\hline \multirow{5}{*}{$\begin{array}{l}\text { Understanding } \\
\text { taxation }\end{array}$} & PP1 & 0,731 & 0,420 & .000 & Valid \\
\hline & PP2 & 0,663 & 0,420 & .000 & Valid \\
\hline & PP3 & 0,779 & 0,420 & .000 & Valid \\
\hline & PP4 & 0,836 & 0,420 & .000 & Valid \\
\hline & PP5 & 0,794 & 0,420 & .000 & Valid \\
\hline \multirow{5}{*}{$\begin{array}{l}\text { Interest selection of } \\
\text { majors }\end{array}$} & MPP1 & 0,798 & 0,420 & .000 & Valid \\
\hline & MPP2 & 0,724 & 0,420 & .000 & Valid \\
\hline & MPP3 & 0,730 & 0,420 & .000 & Valid \\
\hline & MPP4 & 0,678 & 0,420 & .000 & Valid \\
\hline & MPP5 & 0,518 & 0,420 & .000 & Valid \\
\hline
\end{tabular}

Source: Data processed SPSS 22 


\subsection{Reliability Test}

A reusability is a tool for measuring a questionnaire that is an indicator of a variable or a construct. A questionnaire is said to be reliable when one's answer to a statement is consistent over time. A construction or variable is said to be reliable if it gives the Cronbach Alpha value $>0.06$. The following results from the reliability test.

Table 5. Reusability Test Results

\begin{tabular}{|c|c|c|c|}
\hline Variable & $\begin{array}{c}\text { Cronbach } \\
\text { 's Alpha }\end{array}$ & $\begin{array}{c}\text { Reliability } \\
\text { standards }\end{array}$ & Description \\
\hline Quality lecturers & 0.742 & 0.6 & Reliable \\
\hline $\begin{array}{c}\text { Understanding } \\
\text { accounting }\end{array}$ & 0.729 & 0.6 & Reliable \\
\hline Understanding taxation & 0.812 & 0.6 & Reliable \\
\hline $\begin{array}{c}\text { Interest selection of } \\
\text { majors }\end{array}$ & 0.729 & 0.6 & Reliable \\
\hline
\end{tabular}

Source: Data processed SPSS 22

Based on the table above, the reliability test results obtained from the Croncbach's Alpha value show that the Understanding accounting variable value is 0.689 , the Tax Comprehension value is 0.870 , the Quality lecturers value is 0.718 and the student interest variable value in the selection of Taxation Concentration is 0.733 . So it can be concluded that all the questionnaires in this study are reliable or consistent, and they can be used as a research instrument.

\subsection{Classic Assumption Test Results}

The classic assumption test aims to test the assumptions required in the linear regression test to meet the criteria. Whereas for the linear regression test, there are four classical assumptions that are often used, namely the normality test, multicolonary test, and heteroscedicity test.

\subsubsection{Normality Test Results}

The basis for making decisions in the normality test is if the value of Asymp.sig. > 0.05, then the data is normally distributed, so the data is normally distributed. If the value of Asmp.sig $<0.05$, the data is not normally distributed. Following are the results of the normality test:

Table 6. Normality Test Using Kolmogorov-Smirnov (K-S)

\begin{tabular}{|ll|c|}
\hline & & $\begin{array}{c}\text { Unstandardized } \\
\text { Residual }\end{array}$ \\
\hline $\mathrm{N}$ & Mean & 100 \\
Normal Parameters & & .0000000 \\
Most Extreme Differences & Std. Deviation & 2.16484018 \\
& Absolute & .084 \\
& Positive & .082 \\
Test Statistic & Negative & -.084 \\
Asymp. Sig. (2-tailed) & & .084 \\
a. Test distribution is Normal. & $.081^{\text {c }}$ \\
b. Calculated from data. & \\
c. Lilliefors Significance Correction &
\end{tabular}

Based on table 6 it can be seen that the test results using the Kolmogrov-Smirnov non-parametric statistical test obtained the Asymp value. Sig. (2-tailed) 0.081 which is greater than 0.05 . So it is stated that the research data carried out is normally distributed.

\subsubsection{Multicoleniarity Test}

The basis for the decision making of a regression model that is free from multicolonierity is that it has a VIF value of less than 10 and a tolerance value greater than 0.10 . The multicollinearity test results can be seen in the table below:

Table 7. Multicollinearity Test Results

\begin{tabular}{|c|c|c|}
\hline Model & \multicolumn{2}{|c|}{ Collinearity Statistics } \\
\hline & Tolerance & VIF \\
\hline (Constant) & & \\
\hline Understanding accounting &, 816 & 1,226 \\
\hline Understanding taxation &, 853 & 1,172 \\
\hline Quality Lecturer &, 941 & 1,063 \\
\hline
\end{tabular}

Source: Data Processed by SPSS 22

Based on table 4.7 above, it can be seen that the Tolerance value $>0.10$ and the variance Inflation Factor (VIF) $<10$ for all variables in this study. When translated, it can be seen that the accounting understanding variable obtained a Tolerance value of 0.816 , of course this is greater than 0.10 and a VIF value of 1.226 where the value is still less than 10. For the Understanding taxation variables, the Tolerance value of 0.853 is certainly greater than 0.10 . The VIF is 1.172 where the value is still less than 10. For the quality lecturer variable, the Tolerance value of 0.941 is certainly greater than 0.10 and the VIF value is 1.063 where the value is still less than 10 . So it can be concluded that there is no multicolonierity problem, then this regression model is feasible to use.

\subsubsection{Heteroscedasticity Test}

The heteroscedasticity test aims to test whether in the regression model there is an inequality of variance from the residuals of one observation to another. A good regression model is seeing the presence or absence of certain patterns on the scatterplot chart. 


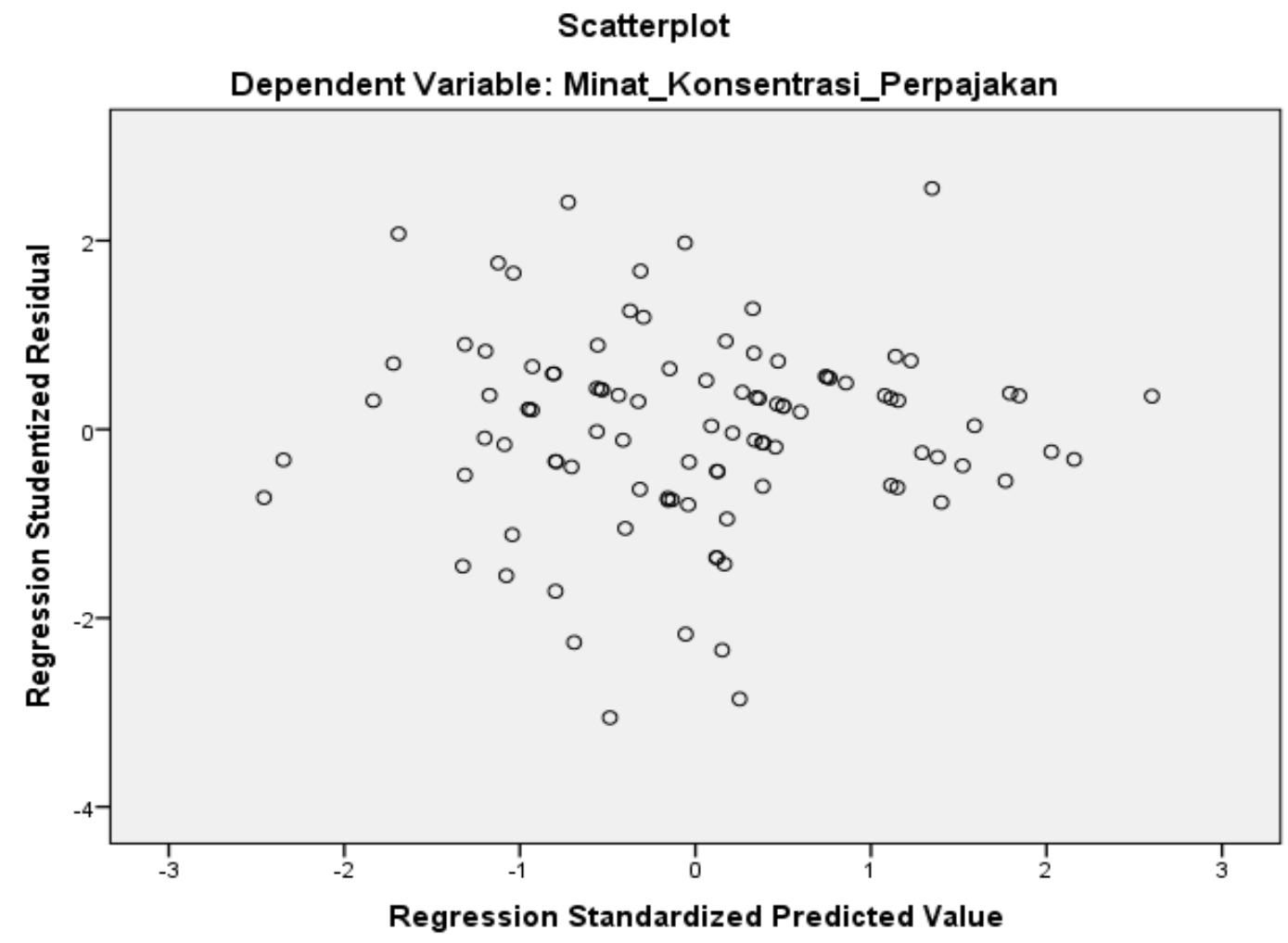

Figure 2. Heteroscedasticity Test Result

Based on the picture above, it can be seen that the dots spread randomly, do not form a clear pattern and the dots spread above and below the 0 (zero) on the $\mathrm{Y}$ axis and there is no clear pattern in the distribution of the data. From the results presented in the image above, it can be concluded that heteroscedasticity does not occur.

\subsection{Hypothesis Test and Discussion}

In this study, using a three-time test model to determine the magnitude of the $t$ test value and the sig level to measure whether there is an effect of each variable. The following is the test model that will be carried out in this study:

Table 8. Test Model 1

\begin{tabular}{|c|c|c|c|c|c|c|}
\hline & \multirow{2}{*}{ Model } & \multicolumn{2}{|c|}{$\begin{array}{c}\text { Unstandardized } \\
\text { Coefficients }\end{array}$} & \multirow{2}{*}{\begin{tabular}{|c|}
$\begin{array}{c}\text { Standardized } \\
\text { Coefficients }\end{array}$ \\
Beta
\end{tabular}} & \multirow{2}{*}{$\mathrm{t}$} & \multirow{2}{*}{$\begin{array}{c}\text { It's } \\
\text { getting } \\
\text { you out } \\
\text { of here }\end{array}$} \\
\hline & & B & $\begin{array}{l}\text { Std. } \\
\text { Error }\end{array}$ & & & \\
\hline \multirow[b]{2}{*}{1} & (Constant) & 11,578 & 1,836 & & 6,305 & ,000 \\
\hline & $\begin{array}{l}\text { Quality } \\
\text { lecturers }\end{array}$ & ,299 & ,122 & ,241 & 2,462 & ,016 \\
\hline
\end{tabular}

a. Dependent variables: Understanding accounting

Based on data analysis, it can be compiled equation of the regression line as follows:

$$
\mathrm{Y}=11,578+0.299 \mathrm{X} 1
$$

The value of Kostanta 11.578 of the above regression equation can explain that if the value of the Quality lecturers variable 0 then the value of Understanding accounting positive value is 11.578 . The value explains that if there is no value change from the lecturer's quality variable the Understanding accounting variable value will still not be changed. However, if the value of the Quality lecturers variable increased by $1 \%$, then the value of the Understanding taxation variable will increase as much as 0.299 adjusted to the change in the competency variable lecturer. The test model above also obtained a $\mathrm{T}$ result table of 2.462 with Sig. amounting to 0.016 . By using the $\mathrm{T}$ distribution table value of 1.984 and a significant level of 0.05 , the test result of model 1 explained that the lecturer's quality variable affects Understanding accounting variables. After the Model 1 test has been implemented then the next stage is Test Model 2 with the following results:

Table 9. Test Model 2

\begin{tabular}{|c|c|c|c|c|c|c|}
\hline & \multirow{2}{*}{ Model } & \multicolumn{2}{|c|}{$\begin{array}{c}\text { Unstandardized } \\
\text { Coefficients }\end{array}$} & \multirow{2}{*}{\begin{tabular}{|c}
$\begin{array}{c}\text { Standardized } \\
\text { Coefficients }\end{array}$ \\
Beta
\end{tabular}} & \multirow{2}{*}{$\mathrm{t}$} & \multirow{2}{*}{$\begin{array}{c}\text { It's } \\
\text { getting } \\
\text { you out } \\
\text { of here }\end{array}$} \\
\hline & & B & $\begin{array}{l}\text { Std. } \\
\text { Error }\end{array}$ & & & \\
\hline \multirow[b]{2}{*}{1} & (Constant) & 15,025 & 1,938 & & 7,754 &, 000 \\
\hline & $\begin{array}{l}\text { Quality } \\
\text { lecturers }\end{array}$ & , 159 & , 128 & ,124 & 1,236 & ,219 \\
\hline
\end{tabular}

a. Dependent variables: Taxation understanding

Based on data analysis, it can be compiled equation of the regression line as follows:

$$
\mathrm{Y}=15,025+0.159 \mathrm{X} 1
$$


The value of Kostanta 15.025 of the above regression equation can explain that if the value of the Quality lecturers variable 0 then the value of Understanding taxation positive value of 15.025 . The value explains that if there is no change in the value of the lecturer, the value of the Pepajakan comprehension variable will remain unchanging. However, if the value of the Quality lecturers variable increased by $1 \%$ then the value of the Understanding taxation variable will increase as much as
0.159 adjusted to the change in the competency variable lecturer. From the test model above also obtained the result $\mathrm{T}$ table of 1.236 with Sig. by 0216 . Using the T distribution table value of 1.984 and a significant level of 0.05 , then the test result of Model 2 explained that the quality variables of lecturers do not affect the variables Understanding taxation. After test Model 2 has been implemented then the next stage is Test Model 3 with the following results:

Table 10. Test Model 3

\begin{tabular}{|c|c|c|c|c|c|c|}
\hline & \multirow{2}{*}{ Model } & \multicolumn{2}{|c|}{ Unstandardized Coefficients } & \multirow{2}{*}{$\begin{array}{c}\begin{array}{c}\text { Standardized } \\
\text { Coefficients }\end{array} \\
\text { Beta }\end{array}$} & \multirow{2}{*}{$\mathrm{t}$} & \multirow{2}{*}{$\begin{array}{l}\text { It's getting } \\
\text { you out of } \\
\text { here }\end{array}$} \\
\hline & & B & Std. Error & & & \\
\hline \multirow{4}{*}{1} & (Constant) & 6,914 & 1,827 & & 3,784 &, 000 \\
\hline & Quality lecturers &, 334 & ,094 & ,318 & 3,547 &, 001 \\
\hline & Understanding accounting &, 184 &, 081 &, 217 & 2,258 &, 026 \\
\hline & Understanding taxation & ,170 & ,077 & ,207 & 2,201 &, 030 \\
\hline
\end{tabular}

A. Dependent variables: The interest in the selection of majors

Based on data analysis, it can be compiled equation of the regression line as follows:

$$
\mathrm{Y}=6,914+0.334 \mathrm{X} 1+0.184 \mathrm{X} 2+0.170 \mathrm{X} 3
$$

The value of Constanta 6.914 of the above regression equation can explain that if the value of a variable quality lecturer, accounting understanding, and taxation understanding 0 then the value of the study selection interest of the Department of the positive value of 6.914. The value explains that if there is no change in the value of the Quality lecturers variables, Understanding accounting, and taxation understanding, the value of the selection interest of the Parallelor field will remain unchanging. However, if the value of the Quality lecturers variable increases by $1 \%$, then the value of the taxation election interest variable will increase as much as 0.334 . When the value of the Understanding accounting variable increases by $1 \%$ The value of the taxation selection interest variable will increase by 0.184 . If the value of the Pepajakan comprehension variable increases by $1 \%$, the value of the taxation selection interest variable will increase by 0.170 . From the test model above also obtained the Results of the table $T$ variable quality lecturer 3.547 with sig. of 0.001 , Understanding accounting Variable with the value of T table of 2.258 with SIG. 0.026, variable Understanding taxation $\mathrm{t}$-value table of 2.201 with SIG. 0.030. Based on the results when testing using the value of distribution table T of 1.984 and a significant level of 0.05 then from the test results Model 3 explained that the quality variables of lecturers, accountability, and Understanding taxation understanding of the interest variables of the major's election. From the test results that have been done it can be described the results in the conceptual framework as follows:

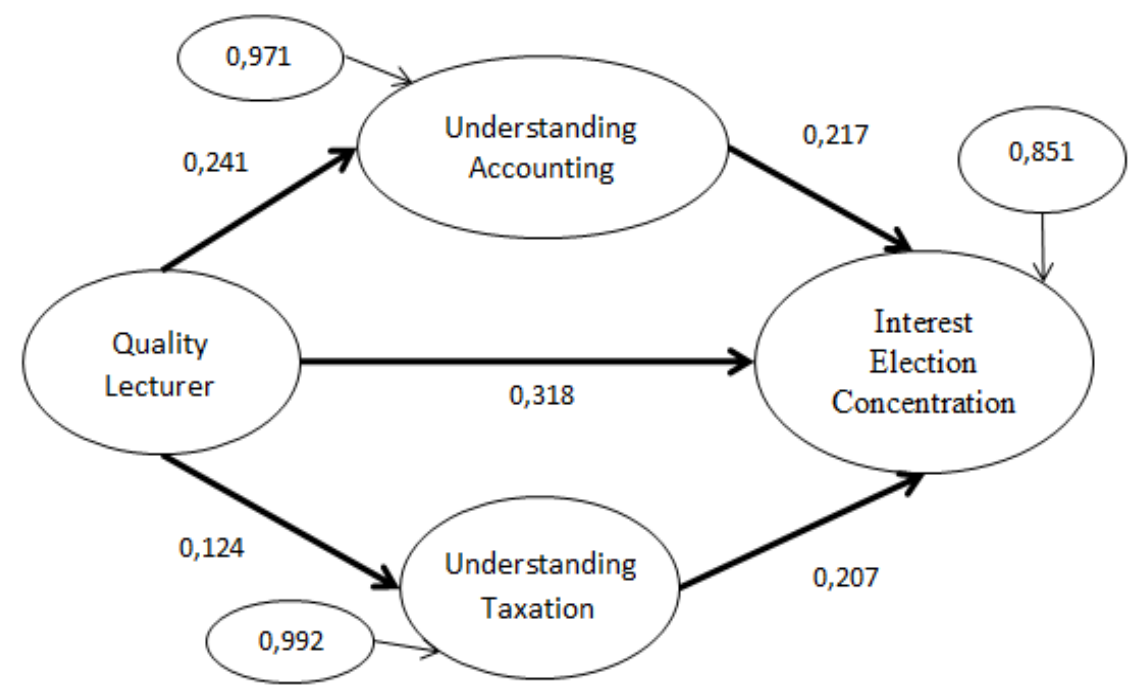

Figure 3. Model Test Results 


\subsection{Test Moderated Regression Analysis (MRA)}

The moderating variable is a variable that can strengthen or weaken another variable. To know the impact of the moderation variables it will be performed a Moderated Regression Analysis (MRA) test. In testing using Test MRA will be done twice the test because in this research two variables are moderating. Before conducting the MRA test it is necessary to know that the results of the R Square of the variable independent of the dependent variable. The variable of Lecturer Competence is the independent variable, while the Interest in Course Selection is the dependent variable. Below is a table of $\mathrm{R}$ Square test results from that variable which can be the basis in the determination of the moderation variables whether it will strengthen or weaken the faculty competency variable.

Table 11. R Square Test of Independent and Dependent Variables

\begin{tabular}{|c|c|c|c|c|}
\hline \multicolumn{5}{|c|}{ Model Summary } \\
\hline Model & $\mathrm{R}$ & R Square & Adjusted R Square & $\begin{array}{c}\text { Std. The error of the } \\
\text { Estimate }\end{array}$ \\
\hline 1 &, $396 \mathrm{a}$ &, 157 &, 148 & 2,347 \\
\hline
\end{tabular}

A. Predictors: (Constant), quality lecturer

From the table above, it is known that the value of $R$ Square influence of competency variables lecturer on the interest of the major's election of 0.157 . The value can be interpreted that the impact of the lecturer's competency variable in the study selection interest of the remaining $15.7 \%$ is affected by other variables outside the variable. The next stage uses the MRA test with the Understanding accounting variable as a moderating variable. Below is a table of test results MRA Model 1 as follows:

Table 12. Test MRA Model 1

\begin{tabular}{|c|c|c|c|c|}
\hline \multicolumn{5}{|c|}{ Model Summary } \\
\hline Model & $\mathrm{R}$ & R Square & $\begin{array}{c}\text { Adjusted R } \\
\text { Square }\end{array}$ & $\begin{array}{c}\text { Std. The error of the } \\
\text { Estimate }\end{array}$ \\
\hline 1 &, $491 \mathrm{a}$ &, 241 &, 217 & 2,250 \\
\hline
\end{tabular}

A. Predictors: (Constant), quality lecturer * Understanding accounting, Quality lecturers, Understanding accounting

From the table above, it is known that the value of $R$ Square with the moderation Understanding accounting variable was obtained as a result of 0.241 . This value can mean that the influence of the lecturer competency variable on the study election interest through the Understanding accounting moderation variable of the remaining $24.1 \%$ is affected by other variables outside of the variable. When comparing the value of R Square in table 6 of 0.157 and table 7 of 0.241 can be concluded that the Understanding accounting variable as a moderation variable can strengthen the impact of the lecturer competency variable on the major's selection interest variable. Next Test MRA Model 2 variable taxation understanding as moderation variables. Below is a table of test results MRA Model 2 as follows:
Table 13. Test MRA Model 2

\begin{tabular}{|c|c|c|c|c|}
\hline \multicolumn{5}{|c|}{ Model Summary } \\
\hline Model & $\mathrm{R}$ & R Square & $\begin{array}{c}\text { Adjusted R } \\
\text { Square }\end{array}$ & $\begin{array}{c}\text { Std. The error of the } \\
\text { Estimate }\end{array}$ \\
\hline 1 &, $609 \mathrm{a}$ &, 370 &, 351 & 2,049 \\
\hline
\end{tabular}

A. Predictors: (Constant), quality Lecturer * Understanding taxation, quality lecturer, taxation understanding

From the table above, it is known that the value of $\mathrm{R}$ Square with variable moderation of taxation understanding obtained the result as 0.370 . This value can be interpreted that the influence of the competency variable of the lecturer against the study election interest through a Understanding taxation moderation variable of $37 \%$ the remainder is affected by other variables outside the variable. When comparing the value of R Square in table 6 of 0.157 and table 8 of 0.370 , it can be concluded that the taxation understanding variable as a moderation variable can strengthen the influence of the competency variable of lecturers on the variable interest in the selection of majors.

\section{Conclusions}

1) The first hypothesized test results showed that the Competency of lecturers has a significant effect on Understanding accounting. It can be concluded that $\mathrm{H} 1$ is accepted.

2) The second hypothesis of the test showed that Lecturer's competence has no significant effect on Taxation understanding. It can be concluded that $\mathrm{H} 2$ in reject.

3) The third hypothesis test results show that the Competency of the lecturer has a significant effect on the Study election interest. It can be concluded that H3 received.

4) Fourth hypothesis testing results show that Understanding accounting has a significant effect on the interest in majors selection. It can be concluded that H4. received.

5) The results of the fifth hypothesis test showed that the Understanding taxation significantly affected the Study election interest. It can be concluded that H5 received.

6) The test results of the MRA model show that the Understanding accounting as a moderating variable can strengthen the influence of Quality lecturers on the interests of study selection. Then it can be concluded that $\mathrm{H} 6$ is accepted.

7) The test results of model MRA showed that the Understanding taxation as a moderation variable was able to strengthen the quality influence of lecturers on the interest selection of majors. Then it can be concluded that $\mathrm{H} 6$ received. 


\section{Limitations}

1) The factors used to test the interest in taxation concentration in this research are limited to Understanding accounting, Understanding taxation, and qualified lecturers.

2) In this study the population and respondents only students from the University of Pamulang only. Furthermore, it is expected to increase the population and respondents from other universities.

\section{Further Research}

1) Further research is expected to develop and expand the scope of research such as other state and private universities to see the students' interest in accounting at wider taxation concentrations.

2) Add new variables to provide more accurate results related to interest in a particular field of knowledge.

\section{REFERENCES}

[1] D. A. Setiawan, "PROFESI AKUNTAN Akuntan Indonesia Leluasa Berpraktik di 10 Negara Asean," DDTCNews Trusted Indonesiaan Tax News Portal. https://news.ddtc.co.id/akuntan-indonesia-leluasa-berprakti k-di-10-negara-asean--17457?page $y=0,2019$.

[2] B. Siregar, "UNIVERSITAS MUHAMMADIYAH YOGYAKARTA Dirikan CPA Test Center, Akuntan RI Disiapkan Go ASEAN," DDTCNews Trusted Indonesiaan Tax News Portal. https://news.ddtc.co.id/dirikan-cpa-test-center-akuntan-ri-di siapkan-go-asean-14799?page $\mathrm{y}=799,2019$.

[3] A. K. Halabi, R. Barrett, and R. Dyt, "Understanding financial information used to assess small firm performance," Qual. Res. Account. Manag., 2010.

[4] E. O'Donnell and J. J. Schultz Jr, "The halo effect in business risk audits: Can strategic risk assessment bias auditor judgment about accounting details?," Account. Rev., vol. 80, no. 3, pp. 921-939, 2005.

[5] K. A. Ahmed, N. Sharif, and N. Ahmad, "Factors Influencing Students' Career Choices : Empirical Evidence from Business Students," vol. 2017, 2017, doi: 10.5171/2017.718849.

[6] M. Syahlina, "ANALYSIS OF FACTORS AFFECTING STUDENTS OF ACCOUNTING STUDENTS USING FEB USU IN THE ERA OF ASEAN ECONOMIC AFFAIRS (MEA) WITH OPPORTUNITIES AND MEAS CHALLENGES FOR ACCOUNTING INDONESIA AS A MODERATING VARIABLE," Int. J. Public Budgeting, Account. Financ., vol. 1, no. 2, 2018.

[7] G. E. Horton and D. Brown, "The importance of interpersonal skills in consultee-centered consultation: A review," J. Couns. Dev., vol. 68, no. 4, pp. 423-426, 1990.
[8] D. W. Johnson, "The importance of interpersonal skills," Shar. Exp. Hum. Commun., pp. 21-49, 1978.

[9] J. Nyamwange, "Influence of Student's Interest on Career Choice among First Year University Students in Public and Private Universities in Kisii County , Kenya," vol. 7, no. 4, pp. 96-102, 2016.

[10] J. Kim and Y. Hwang, "The Effects of School Choice on Parental School Participation and School Satisfaction in Korea," 2012, doi: 10.1007/s11205-012-0224-4.

[11] Y. Lee, C. Chao, and C. Chen, "The influences of interest in learning and learning hours on learning outcomes of vocational college students in Taiwan: using a teacher' $s$ instructional attitude as the moderator," vol. 13 , no. 3 , pp. 140-153, 2011.

[12] J. M. Harackiewicz, J. L. Smith, and S. J. Priniski, "HHS Public Access,” 2018, doi: 10.1177/2372732216655542.Int erest.

[13] O. S. Pitan and S. O. Adedeji, "Students' choice of courses : Determining factors, sources of information, and relationship with the labour market demands in Nigeria," no. March, pp. 37-41, 2015, doi: 10.1080/18146627.2014.9349 97.

[14] A. Sarwar, "FACTORS AFFECTING SELECTION OF SPECIALIZATION BY BUSINESS FACTORS AFFECTING SELECTION OF SPECIALIZATION," no. January 2015, 2017.

[15] C. Albert and C. Garc1, "outcomes in Spain," pp. 559-582, 2010, doi: 10.1007/s10734-010-9315-9.

[16] M.-F. Chen and P.-J. Tung, "Developing an extended theory of planned behavior model to predict consumers' intention to visit green hotels," Int. J. Hosp. Manag., vol. 36, pp. 221230,2014

[17] M. Conner and C. J. Armitage, "Extending the theory of planned behavior: A review and avenues for further research,” J. Appl. Soc. Psychol., vol. 28, no. 15, pp. 14291464, 1998.

[18] L. Beck and I. Ajzen, "Predicting dishonest actions using the theory of planned behavior," J. Res. Pers., vol. 25, no. 3, pp. 285-301, 1991.

[19] D. M. Randall, "Why students take elective business ethics courses: Applying the theory of planned behavior," J. Bus. Ethics, vol. 13, no. 5, pp. 369-378, 1994.

[20] K. R. Amanda and M. M. D. Restuti, "Faktor-Faktor yang Mempengaruhi Niat Penggunaan Sistem Informasi Terkomputerisasi pada UKM (Pendekatan Theory of Planned Behavior)," J. Akunt. Maranatha, vol. 9, no. 1, pp. 23-33, 2018, doi: 10.28932/jam.v9i1.489.

[21] J. Downey, "An empirical examination of the composition of vocational interest in business colleges: MIS vs. other majors,” J. Inf. Syst. Educ., vol. 22, no. 2, p. 7, 2019.

[22] Goverment, Undang-Undang Republik Indonesia No 12 Tahun 2012 tentang Pendidikan Tinggi, vol. 66. 2012, p. 769.

[23] S. Saada, E. K. Ghanib, K. Muhammadc, A. H. Ismaild, M. R. M. Dangie, and M. M. Saatf, "Assessing technology competency of small and medium accounting practitioners 
in Cambodia: A qualitative investigation," Int. J. Innov. Creat. Chang., vol. 11, no. 8, pp. 533-552, 2020.

[24] M. H. Kavanagh and L. Drennan, "What skills and attributes does an accounting graduate need? Evidence from student perceptions and employer expectations," Account. Financ., vol. 48, no. 2, pp. 279-300, 2008.

[25] M. Suwardjono, “Accounting Theory.” BPFE, Yogyakarta,
2005.

[26] R. A. Nugroho and Z. Zulaikha, "Faktor-Faktor Yang Mempengaruhi Kemauan Untuk Membayar Pajak Dengan Kesadaran Membayar Pajak Sebagai Variabel Intervening (Studi Kasus Wajib Pajak Orang Pribadi Yang Melakukan Pekerjaan Bebas Yang Terdaftar Di KPP Pratama Semarang Tengah Satu).” Fakultas Ekonomika dan Bisnis, 2012. 